\title{
Geological, Geochemical, and Radiometric Study of Sandstone-Type Uranium Deposit Exploration in Menukung Area, West Borneo
}

\author{
Wira Cakrabuana*, Ekky Novia Stasia Argianto, Roni Cahya Ciputra, Dhatu Kamajati \\ Center for Nuclear Minerals Technology, National Nuclear Energy Agency (PTBGN-BATAN), \\ Lebak Bulus Raya St. No. 9, Pasar Jumat, Jakarta, 12440, Indonesia \\ *E-mail: wira.cakrabuana@batan.go.id
}

Article received: 6 February 2021, revised: 26 February 2021, accepted: 26 February 2021

DOI: 10.51835/iagij.2021.1.1.15

\begin{abstract}
BATAN has been carried out uranium exploration in West Borneo since 1969. So far, the exploration is focused on metamorphite-type uranium deposits in Kalan Area. The previous study concluded that mineralized uranium is originated from Sepauk Tonalite consisted of felsic-intermediate igneous rocks, and is hosted in medium-grade foliated and non-foliated metamorphic rocks of Pinoh Metamorphite. As uranium exploration develops, the International Atomic Energy Agency (IAEA) introduces the sandstone-type uranium mineralization concept that offers a more cost-effective mining process. The Melawi Basin becomes an attractive probable location for sandstone-type uranium deposit exploration since it is situated downstream of Schwaner Mountain's Sepauk Tonalite. The sandstone-dominated Tebidah Formation of Melawi Basin can be the host rock for sandstone-type uranium deposit if there is a reduction zone to trap the mobile uranium in the groundwater. The geological mapping, geochemical sampling, and radiometric survey were conducted in Menukung Area to prove the hypothesis. It is located in the eastern part of the Tebidah Formation, which contains abundant carbonaceous mudstones associated with coal seams. Mobile uranium content analysis showed the anomaly of 36-60 ppm at the central of Tebidah Formation at the study area, while radiometric data denoted the anomaly of 6.5-11.3 ppm eU. At those locations, coal and carbonaceous sandstone were observed. Those data indicate the presence of a reductive environment that gives the advantage to uranium trapping. It can be concluded that there is a possibility of the occurrence of sandstone-type uranium mineralization in the Menukung Area.
\end{abstract}

Keywords: Sandstone-type uranium, Tebidah Formation, Menukung, Geochemical, Radiometric

\section{INTRODUCTION}

The study respecting uranium mineralization in West Borneo has been carried out since 1969 [1]. Generally, the study is focused on exploring the occurrence of metamorphite-type uranium deposits in the Kalan Area [1]. The uranium mineralization in the area is indicated by the high value of radioactivity [2].

The exploration activities in the Kalan Area consist of geological observation, geophysical survey, radiometric measurement, geochemical and core sampling $[1,2,3]$. Based on that research, it is concluded that mineralized uranium in Kalan Area is originated from Sepauk Tonalite that consisted of felsic-intermediate igneous rocks and hosted in Pinoh Metamorphite that consisted of medium-grade foliation and nonfoliation metamorphic rocks $[1,2,3]$.

As uranium exploration develops, the International Atomic Energy Agency (IAEA) introduces the sandstone-type uranium mineralization concept that offers a more cost-effective mining process [4]. Tebidah Formation dominated by sandstones which overlays Sepauk Tonalite, appears the hypothesis of sandstone-type uranium 
mineralization occurrence. Geological mapping, geochemical sampling, and radiometric surveys are undertaken in Menukung Area, West Borneo, to prove the hypothesis.

\section{DATA AND METHODS}

The study area is administratively located in Menukung and Ella Hilir Districts, Melawi Regency, West Borneo Province. The location map [5] of the study area is depicted in Figure 1. According to the UTM coordinate system, the study area is $20 \mathrm{~km} \mathrm{x}$ $20 \mathrm{~km}$ in extent and located on 620000- 640000m E; 9940000-9960000m S. This area is approximately $100 \mathrm{~km}$ away southeastward from BATAN Nuclear Minerals office in Nanga Pinoh District. This area can be reached by a two-wheeled or four-wheeled vehicle. The track is $75 \%$ asphalted, and the rest is a rocky track heading to the study area. The route map of the study area is depicted in Figure 2. Based on the DEM image interpretation, Menukung Area consists of hills on the southern part and a low plain in the northern region. The geomorphological map of the study area is depicted in Figure 3.

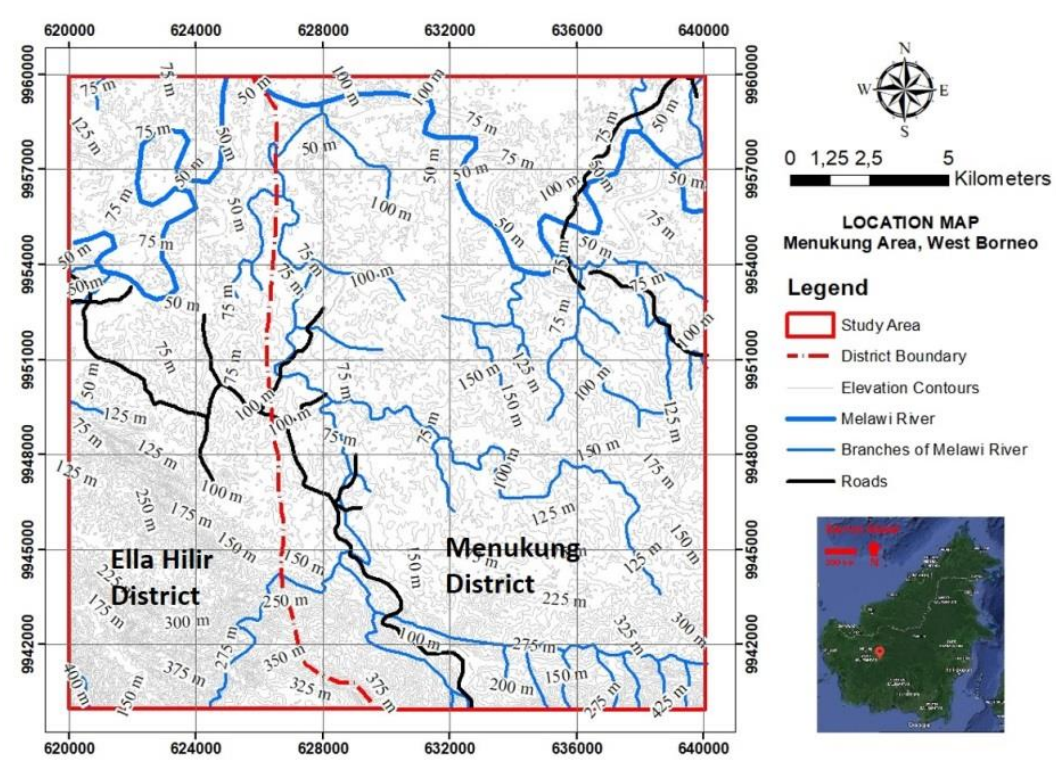

Figure 1. The location map of the study area [5]

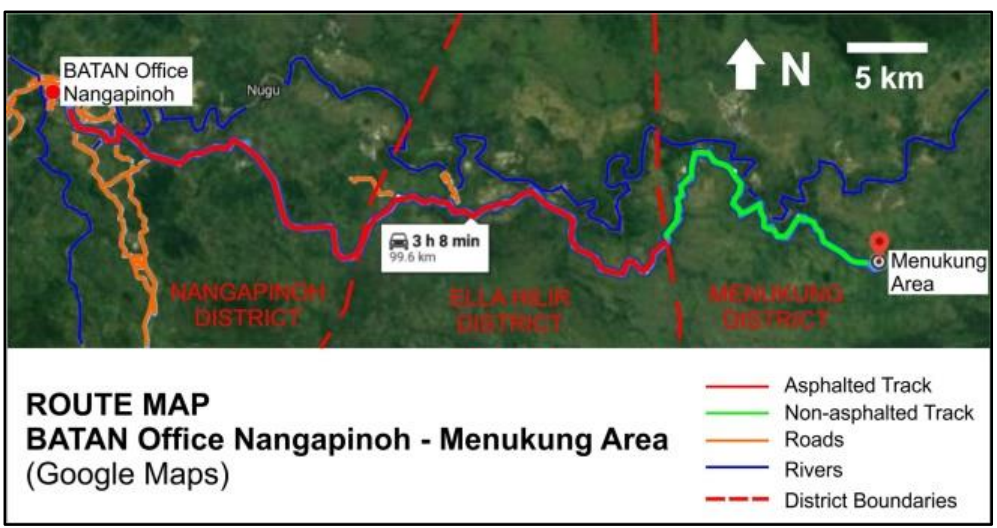

Figure 2. The route map of the study area 


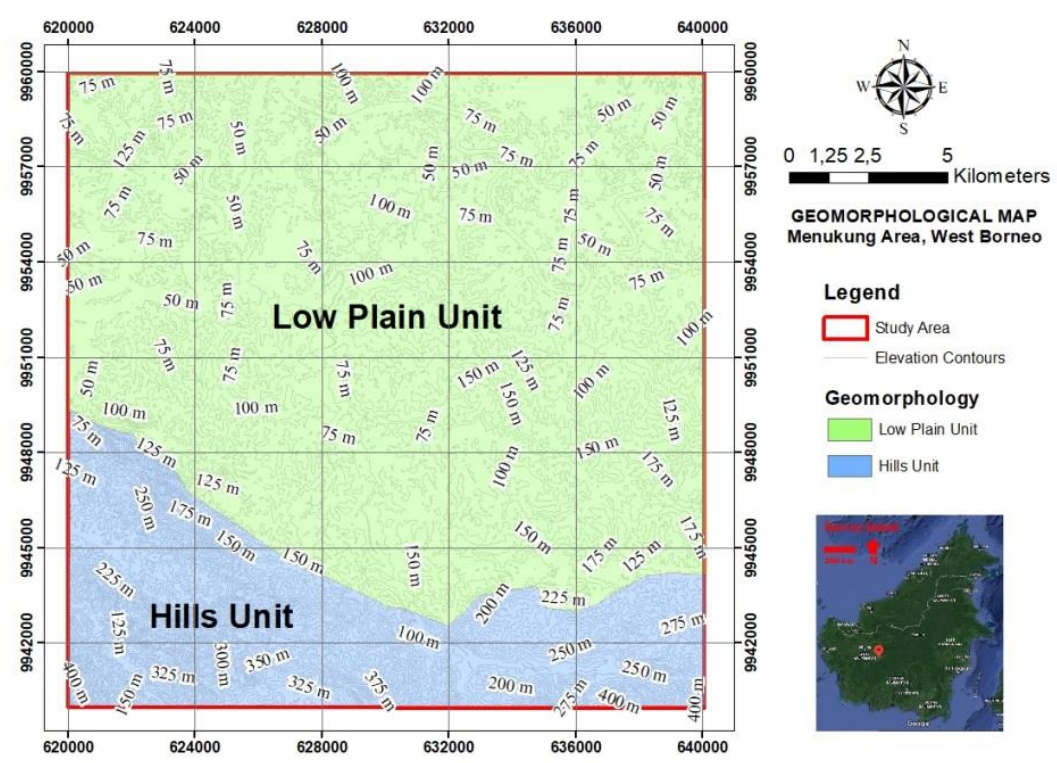

Figure 3. The geomorphological map of the study area

Geologically, the study area is situated in the Melawi Basin. The Melawi Basin sequence based on sedimentary structures, fossils, and macerals in each formation [6] began with the Ingar Formation deposition in the deep outer shelf to the upper slope environment. After a period of uplift and erosion, Dangkan Sandstone deposition in the low sinuosity fluvial environment followed by Silat Shale deposition in the lagoon to marine trough and marginal marine deposits. The second period of folding happened along the northern margin of the basin. It was followed by the Payak Formation deposition in the land to a shallow marine environment in the north part of the basin. In the southern part of the basin, Sepauk Sandstone (which is classified as the western sandstone unit of Tebidah Formation in newer reference [6]) was deposited as a fluvial channel to nearshore marine sands. The marginal marine deposits of the lower Tebidah Formation partially interdigitated with two previous formations then passed gradationally up into floodplain and isolated channel sand deposits. Sekayam Sandstone's deposition in a highenergy fluvial environment in the western part of the basin happened after a further tectonic period. In the eastern region, the Alat Sandstone was deposited by low sinuosity to meandering streams.

Menukung Area, from the oldest to the youngest, consists of Pinoh Metamorphite, Sepauk Tonalite, and Tebidah Formation [7] (Figure 4). Pinoh Metamorphite is a Carboniferous-Triassic metamorphic rocks complex consists of muscovite-quartz schist, phyllite, slate, hornfels, some meta-tuff; quartzite, andalusite, cordierite, and biotite in places; sillimanite and garnet rare [7]. Sepauk Tonalite is a Lower Cretaceous igneous rocks complex consisting of light grey biotitehornblende tonalite and granodiorite; some diorite and granite monzodiorite, and quartz diorite [7]. Tebidah Formation is an Upper Oligocene sedimentary rocks formation that consists of fine-grained sandstone interbedded with green and red mudstone in the upper part and with grey mudstone and siltstone in the lower part; thin coal seams in places [7]. The geological structures controlling this area are lineaments which probably in the form of faults, fractures, and joints [7]. 


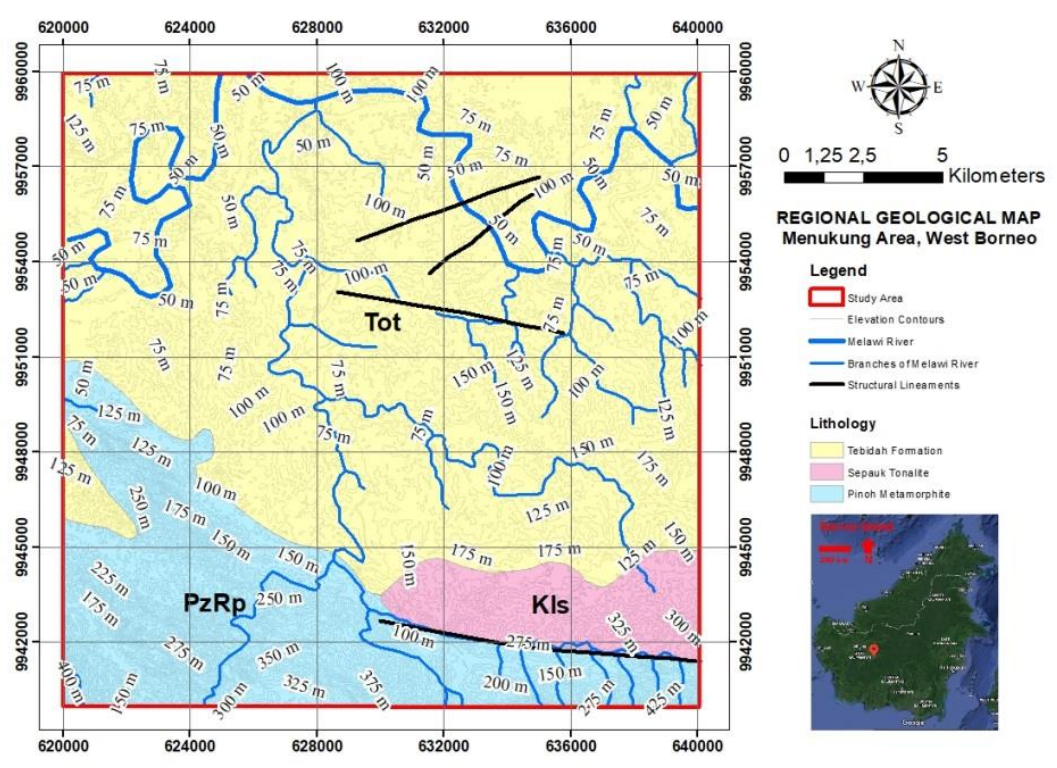

Figure 4. The regional geological map of the study area [7]

The sandstone-type uranium deposit is a uranium deposit formed in the sandstone host rock [4]. This type of mineralization is more probable to occur in a fluvial environment than in the marine environment [4]. The prevalent host rocks found are fluvialshallow marine sandstones [4]. The age of this mineralization type is Paleozoic-Tertiary [4]. Most of the sandstone-type uranium deposits are formed in diagenetic-epigenetic zones (low temperature) [4]. Based on the mineralization morphology and geological setting, sandstone-type uranium deposits are classified into five types: basal-channel, tabular, roll-front, tectonic-lithologic mafic dykes-sills in Proterozoic sandstone [4]. The scheme of sandstone-type uranium deposits [4] is depicted in Figure 5.

Most sedimentary-type uranium deposits are associated with uranium-enriched geochemical provinces of intrusive or volcanic rocks. However, the source rocks have a distance away from the deposit by tens of kilometers or more [8]. The geochemical detection of uranium deposits in sedimentary rocks, especially sandstone-type deposits, depends on uranium and pathfinder elements' geochemical behavior. Uranium is extensively dispersed under oxidizing conditions but is immobile under reducing conditions [8]. An anomaly may be present in stream sediments only if the ore-bearing rocks are exposed to active erosion.

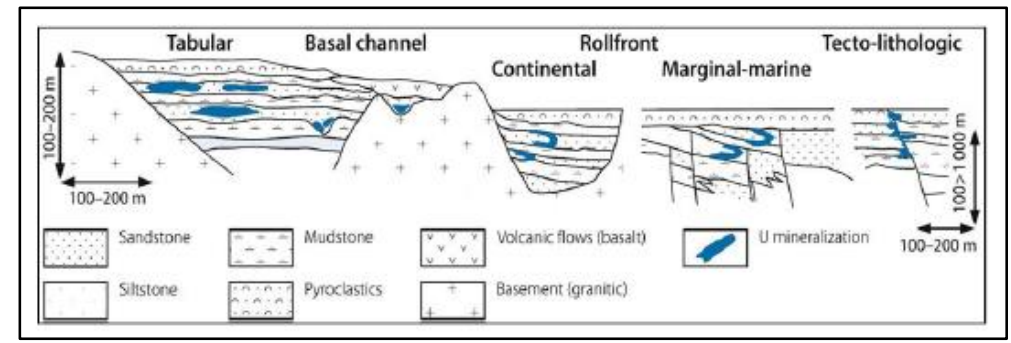

Figure 5. The scheme of sandstone-type uranium deposits [4] 
In contrast, strata-bound deposits in the unexposed and concealed host rock are much more difficult to detect by stream sediment [8]. The exploration situation for uranium in sedimentary rock [8] is depicted in Figure 6. Due to the net negative charge in their clay layers that needs to be balanced by interlayer cations, clay minerals on the fine fractions of soils containing clays, colloids, oxides, and organic matters can absorb the mobile uranyl ions more readily. Thus, fine-grained soils enriched with clays, oxides, and colloids are useful pathfinders for regional geochemical exploration in sedimentary basins [9].

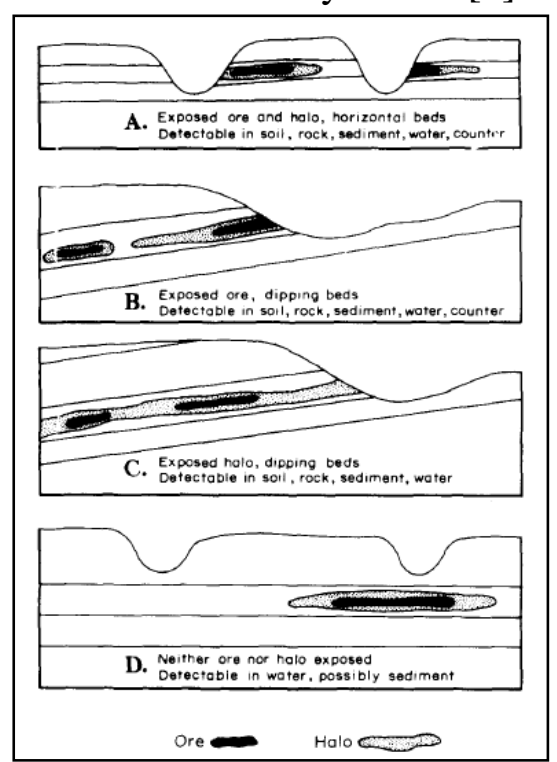

Figure 6. Exploration situation for uranium in sedimentary rock [8]

At some proven sandstone-hosted uranium, such as the Sifangtai Formation of NE China, the interconnected channel bar from the braided-meandering river depositional system are the ore-hosting sandstones that have good reservoir property [6]. The distributary channels of the environment are correlated to the deposition of strong interlayer oxidation and uranium mineralization, as recorded in Turpan-Hami Basin, China [10]. The braided-meandering river's strong hydrodynamic conditions also bring many terrestrial organic materials, which is good for the adsorption of sulfur and uranium produced [11].

Based on sedimentary structures, fossils, and macerals in each formation, the depositional environment sequence of the Melawi Basin was explained [11]. The lower Tebidah Formation's western facies, also known as Sepauk Sandstone by petroleum exploration companies [11], overlies the Schwaner Zone's basement rocks. The succession is characterized by poorly defined fining upward sequences starting with coarsegrained passing upward into finer-grained flat and cross-bedded sandstone, which is interpreted to represent fluvial channel deposits derived. Meanwhile, the lower Tebidah Formation's eastern facies is characterized by very fine sandstone with symmetrical cross-bedding and parallel lamination infixed in the mudstone that represented subtidal facies of tidal flat. In the middle succession of this formation, the planar lamination and cross-bedding become thicker up to $2 \mathrm{~m}$ on the medium to coarsegrained sand, followed by gradation to finer sandstone succession, indicating a fluvial channel environment. At the upper part, the symmetrical ripple mark with laminated cross-bedding in the fine to very fine sandstone associated with parallel lamination and carbonaceous layer at the top represents tidal flat environment shifting into floodplain environment.

The sandstone succession in the middle part of the Tebidah Formation could be the host for uranium. The porosity is also suitable for the reservoir as secondary porosity produced by the dissolution of feldspar and volcanic rock grains is recorded from Tebidah Formation sandstone [11]. The depositional environment shifting makes lithologies that 
have the potential to be a trap for uranium mineralization. The upper finer-grained lithologies can be a good seal for the underlain sandstone. It is also associated with the carbonaceous layer that can act as uranium absorbent or reductant. Having wide distribution, lateral facies shifting of Tebidah Formation was also considered in the possibility of the uranium reduction process. Since the abundance of carbonaceous material containing mudstone associated with coal seams increase eastward [11,12], the Tebidah Formation of Menukung Area was chosen.

Analysis of uranium mineralization on sandstone and surficial deposit related to paleo valley in China and Australia [13] resulted in four essential components: 1) source rocks (i.e., leachable uranium, vanadium, and potassium) connected to the paleo valley systems; 2) paleo valley or basin margins (i.e., transport pathway and site of accumulation); 3) physical and chemical environments for mineralization (e.g., paleogeomorphology, groundwater flux, salinity, $\mathrm{pH}$, Eh, climatic conditions); and 4) pre-and post- mineralization settings for preservation (e.g., muddy layers, faulting, erosion).

The study was divided into three parts. They were preparation, field activity, and comprehensive analysis. The preparation was carried out by a literature review of previous researches, base map production, instrument setup, and route planning for the field activity. The field activity was carried out by geological mapping, geochemical sampling, radiometric survey, and data processing. Comprehensive analysis is carried out by the production of various field data-based maps and a study report.

Geological mapping was conducted at 1:125000 scale. The mapping is prioritized to be done along the available road access to make the activity easier. If there is a particular feature to observe and the condition is feasible, the mapping can be done along the river. The mapping is started with interpreting the DEM image of the area to determine the geomorphological landscape and structural lineaments. The mapping was focused on mapping the oxidation and reduction zones in Tebidah Formation. The oxidation zone was represented by sandstones, while claystone, siltstones, and coals represented the reduction zone. The redox boundary could be determined as a potential uranium mineral trapping site by mapping those two zones.

The sample type collected in this study was stream sediment. Geochemical sampling of stream sediment samples was referred to as IAEA Geochemical Exploration Procedure [14]. The stream sediment sampling principle is collecting the representative sample from every river branch consistently [14]. The collection of stream sediment samples was done by grabbing the wet river sediment weighed $1 \mathrm{~kg}$. The samples were grabbed using a shovel and were wrapped using thick plastic wrap. The stream sediment sampling scheme [14] is depicted in Figure 7. In the stream sediments, uranium and other trace elements are concentrated in the fine-sized fraction. Accordingly, in prospecting, grain size fractions less than $90 \mu \mathrm{m}$ (170 mesh) should be analyzed for uranium concentration [15]. As much as $0.2-0.5 \mathrm{~kg}$ dry stream sediment sample is needed for uranium concentration analysis [16], it has to be anticipated that collected wet samples can result in dry samples as much as possible. The analysis of mobile uranium concentration was conducted using Jahrrel Ash Fluorometer Type G-M30116. 


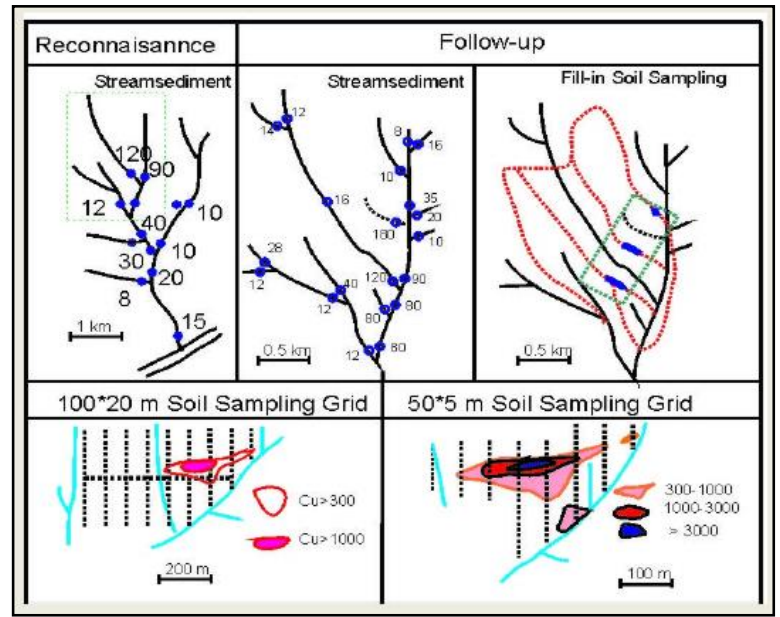

Figure 7. The stream sediment sampling scheme [14]

In this study, radioactivity is measured by Radiometric Spectrometer 125 (RS 125). Before the measurement, RS 125 has to be stabilized and be connected to GPS first. The measurement is carried out in survey mode and assay mode. In survey mode, the measurement is done along the field route with RS 125 turned on. In assay mode, the measurement is done at every attended field station by measuring a particular object's radioactivity. The priority of the object should be measured by assay mode is rocks outcrops first and then the environment. RS-
125 measures the equivalent concentration only of uranium.

A comprehensive analysis was conducted to conclude all field data collected. The entire field data collection were analyzed comprehensively and presented in the geological map, radiometric map, and research report.

\section{RESULTS AND DISCUSSION}

Based on the geological field mapping result at 1:125000 scale, from the oldest to the youngest, Menukung Area consisted of Pinoh Metamorphite, Sepauk Tonalite Tebidah Sedimentary Rocks Units. Tebidah Sedimentary Rocks, as defined in the geological map, is divided into Tebidah Sandstone 1 Unit, Tebidah SandstoneClaystone Unit, and Tebidah Sandstone 2 Unit based on the field observation. Some young coal seams (possibly sub-bituminous) and lignite are observed on Tebidah Sandstone-Claystone Unit. Rocks outcrops map and geological map are depicted in Figure 8 and Figure 9.

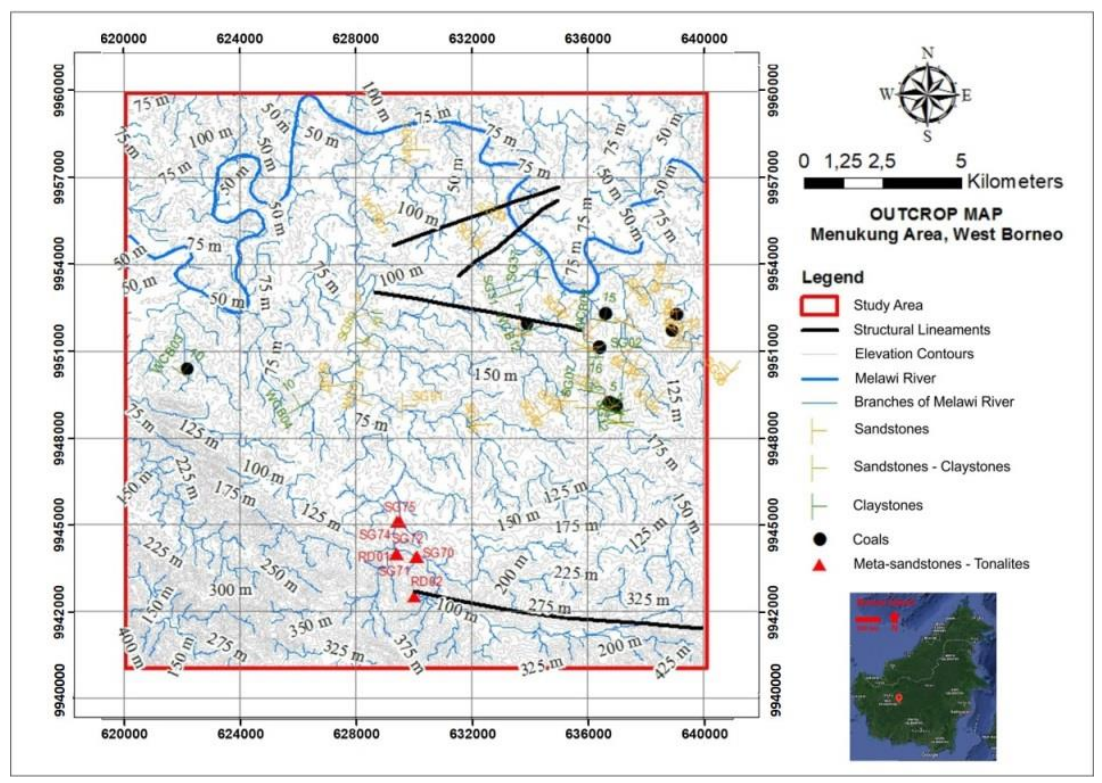

Figure 8 . The rocks outcrop map of the study area 


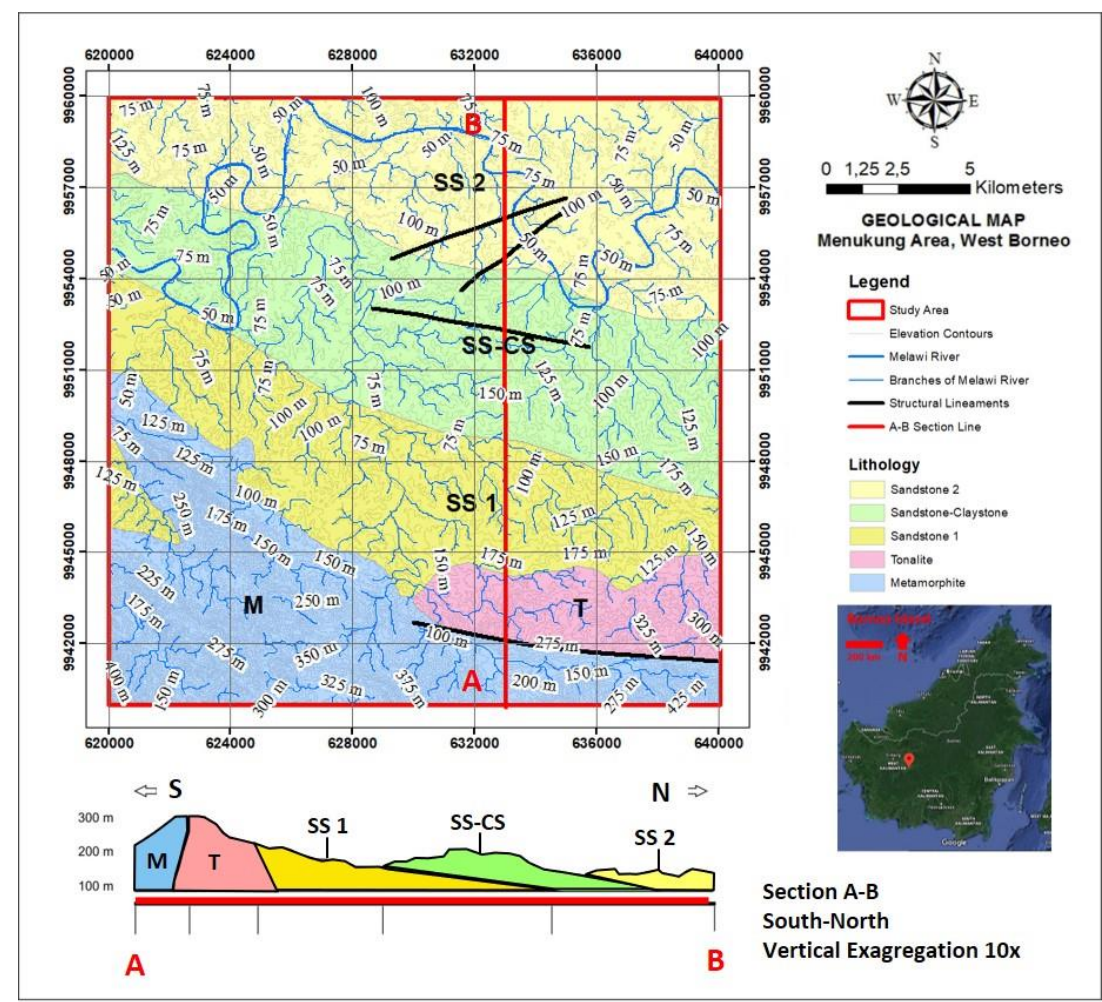

Figure 9. The geological map of the study area

There were 85 stream sediment samples collected in this study for geochemical sampling purposes. Those samples originated from many minor branched rivers at the east part of the study area and the Ella Hulu River (with one of its branches) at the west part of the study area. The samples are in the form of wrapped and labeled $1 \mathrm{~kg}$ wet sediment. A map showing the locations of the stream sediment sampling is depicted in Figure 10. After the wet sediment samples are treated, they are analyzed for mobile uranium content using the fluorimeter. The mobile uranium content ranged from $3.4 \mathrm{ppm}$ to $61.5 \mathrm{ppm}$, with a mean of $17.1 \mathrm{ppm}$. The summary statistics of the analysis result are attached in Table 1. Using formula $\mathrm{M}+2 \mathrm{SD}$ (M: mean, SD: standard deviation), the anomaly value of mobile uranium content was determined (36.1 ppm). The analysis result was then displayed in the form of a content distribution map. There are some anomalous zones at the central and western parts of the study area (mostly on the Tebidah Sandstone-Claystone Unit). The map showing the content distribution of mobile uranium is depicted in Figure 11. 


\section{IAGI Journal}

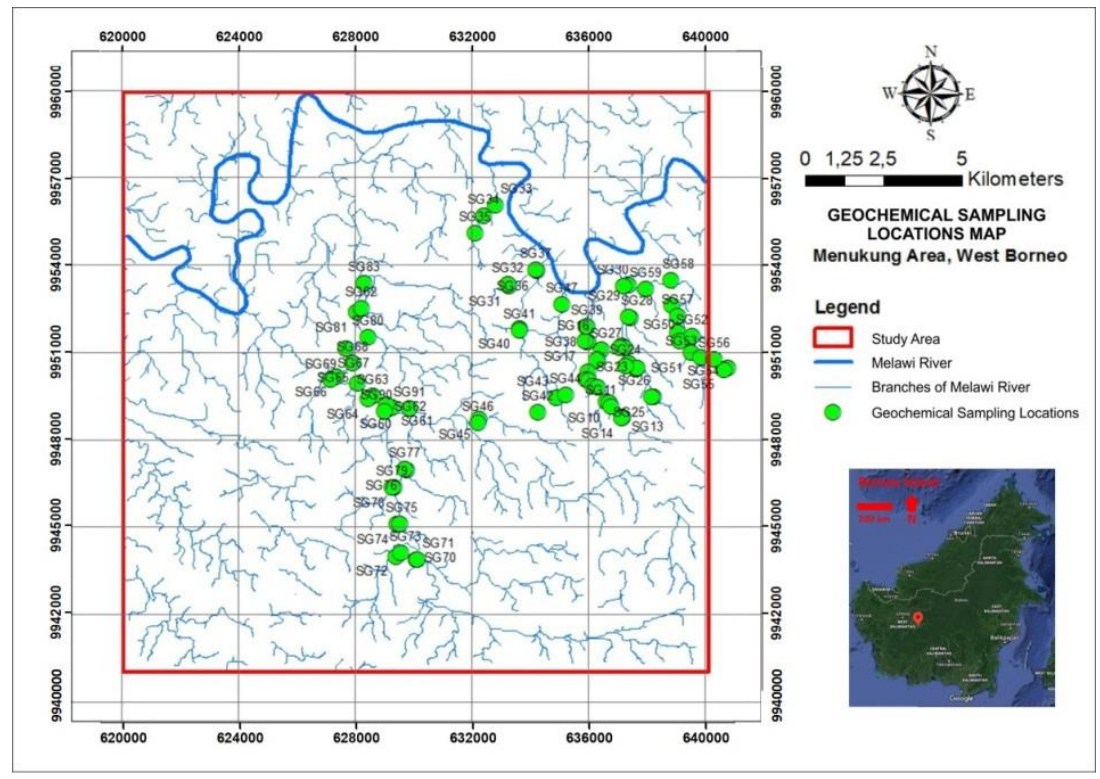

Figure 10. The geochemical sampling locations map

Table 1 . The summary statistics of the mobile uranium content data

\begin{tabular}{lr}
\hline Statistic & Mobile Uranium Content $\mathbf{( p p m ~ U ) ~}$ \\
\hline Mean & 17.07202381 \\
Standard Error & 1.039727801 \\
Median & 14.755 \\
Mode & 11.24 \\
Standard Deviation & 9.529262703 \\
Sample Variance & 90.80684766 \\
Kurtosis & 8.286029376 \\
Skewness & 2.525101442 \\
Range & 58.12 \\
Minimum & 3.39 \\
Maximum & 61.51 \\
Count & 84 \\
\hline Anomaly & $\mathbf{3 6 . 1 3 0 5 4 9 2 2}$ \\
\hline
\end{tabular}

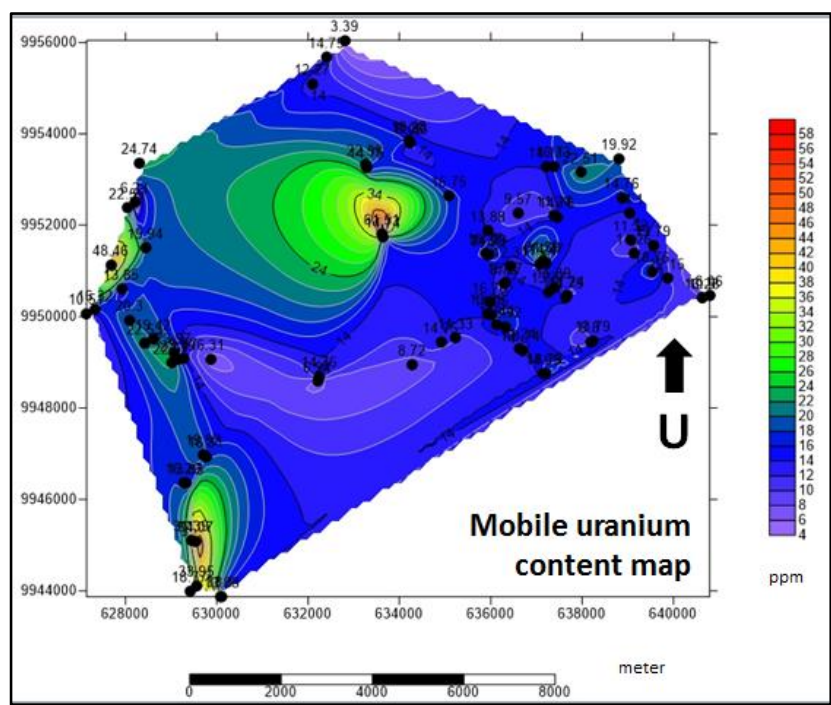

Figure 11. The mobile uranium content map of the study area 
The equivalent concentration of uranium ranged from $0 \mathrm{ppm}$ to $11.3 \mathrm{ppm}$ with a mean of $2.5 \mathrm{ppm}$. The summary statistics of the measurement result are attached in Table 2. Using formula $M+2 S D$, the anomaly value of uranium equivalent concentrations was determined $(6.6 \mathrm{ppm})$. It can be seen on Figure 12, that there are anomalous zones on the central and western part of the study area (mostly on the Tebidah Sandstone-Claystone Unit).

Table 2. The summary statistics of uranium equivalent concentration data

\begin{tabular}{lr}
\hline Statistic & $\begin{array}{l}\text { Equivalent Uranium Concentration } \\
\text { (ppm eU) }\end{array}$ \\
\hline Mean & 2.520430108 \\
Standard Error & 0.211483988 \\
Median & 2.2 \\
Mode & 0 \\
Standard Deviation & 2.039477722 \\
Sample Variance & 4.159469378 \\
Kurtosis & 3.106985145 \\
Skewness & 1.367287344 \\
Range & 11.3 \\
Minimum & 0 \\
Maximum & 11.3 \\
Sum & 234.4 \\
Count & 93 \\
\hline Anomaly & $\mathbf{6 . 5 9 9 3 8 5 5 5 1}$ \\
\hline
\end{tabular}

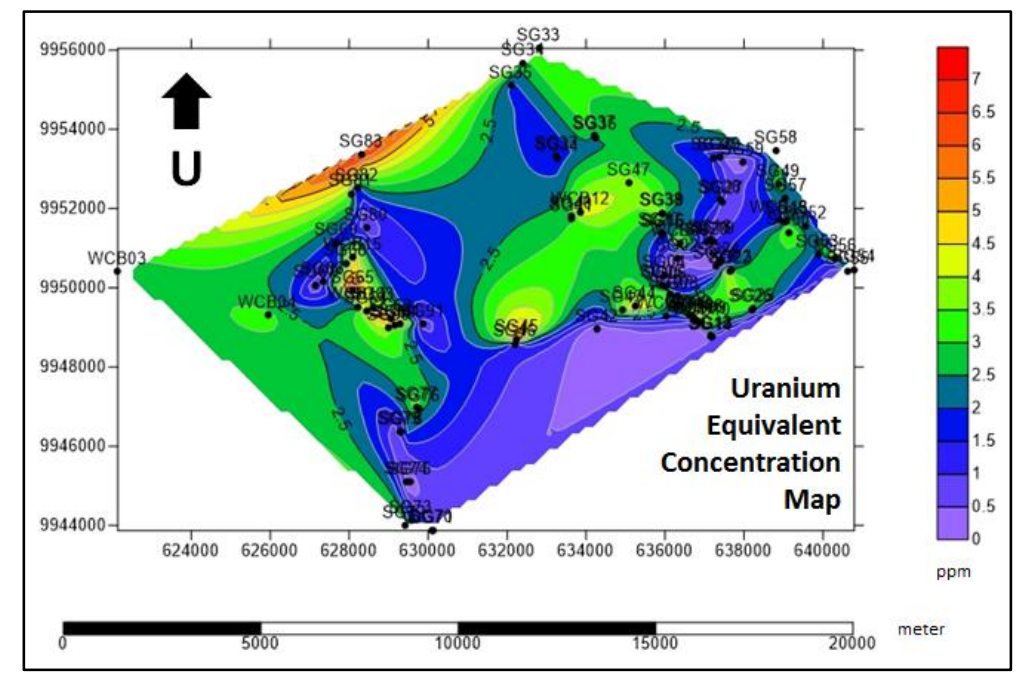

Figure 12. The uranium equivalent concentration map of the study area

Based on all methods applied in this study, it is concluded that Tebidah SandstoneClaystone Unit is the reduction zone and Tebidah Sandtone Unit is the oxidation zone, so a redox boundary is a potential trapping spot of uranium minerals that can be drawn on the boundary of those units. The conceptual scheme of the redox boundary is depicted in Figure 13. 


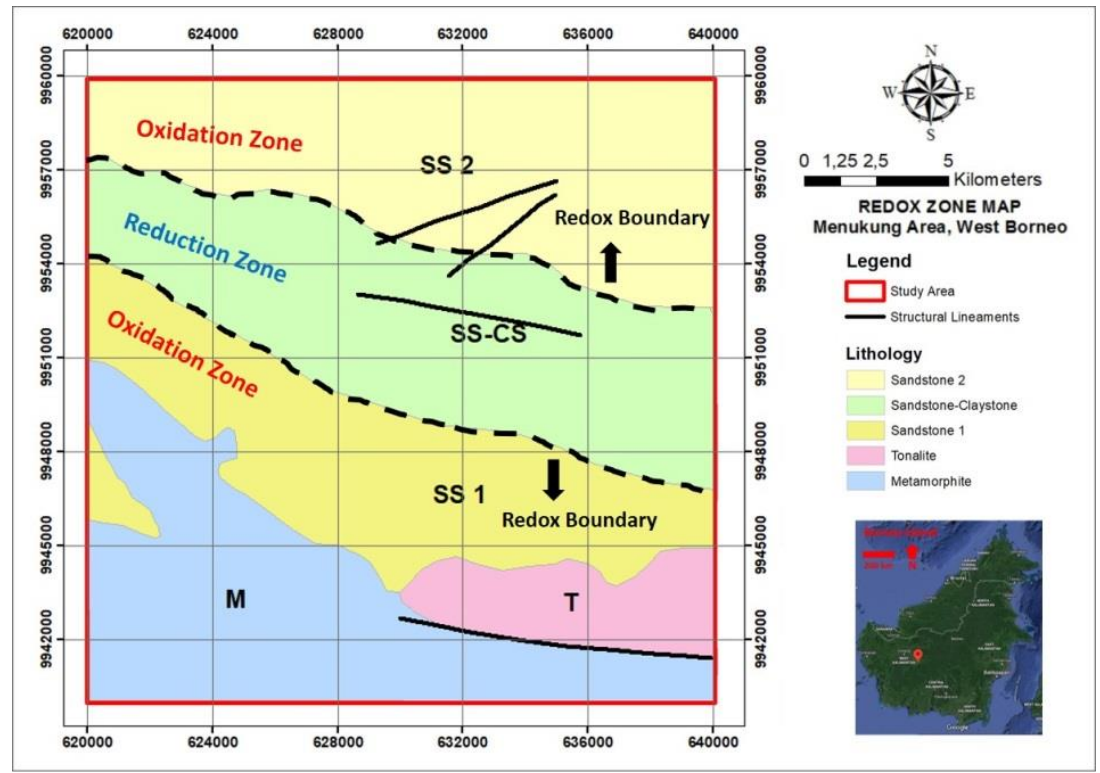

Figure 13. The conceptual scheme of the redox boundary

\section{CONCLUSIONS}

Menukung Area consisted of five rock units, from the oldest to youngest. They are Pinoh Metamorphite Unit, Sepauk Tonalite Unit, Tebidah Sandstone 1 Unit, Tebidah Sandstone-Claystone Unit, and Tebidah Sandstone 2 Unit. Most of the Tebidah Sandstone-Claystone Unit rocks are carbonbearing, giving this unit a big possibility to be uranium precipitant. Both mobile uranium content and uranium equivalent concentration show anomalous zones on the study area's central and western parts (mostly on the Tebidah Sandstone-Claystone Unit). This study concluded that the Tebidah SandstoneClaystone Unit is the reduction zone and the Tebidah Sandstone Unit is the oxidation zone. A redox boundary can be made on the boundary of those units.

\section{ACKNOWLEDGMENTS}

The writers send the high gratitude for Mr. Yarianto Sugeng Budi Susilo as the Head of Center for Nuclear Minerals Technology, Mr. Heri Syaeful as the Coordinator of
Exploration Division, and Mr. Sartapa as the expert in radioactive minerals exploration who has facilitated this research from the beginning to the end.

\section{REFERENCES}

1. Tjokrokardono, S.; Soetopo, B.; Subiantoro, L.; Widana, K.S. Geologi dan Mineralisasi Uranium Kalan, Kalimantan Barat. In Kumpulan Laporan Hasil Penelitian Tahun 2005; BATAN: Jakarta, 2005; pp. 27-52.

2. Suntoko, H.; Soetopo, B. Kajian Aspek Geologi dan Potensi Mineral Uranium di Kalimantan Barat untuk Persiapan PLTN. J. Pengemb. Energi Nukl. 2013, 15, 103-114.

3. Sartapa; Sukadana, I.G. Geologi dan Mineralisasi Uranium di Sektor Sarana Kalan, Kalimantan Barat berdasarkan Data Pemboran. Eksplorium 2011, 32, 91-102, doi:http://dx.doi.org/10.17146/eksploriu m.2011.32.2.2816.

4. International Atomic Energy Agency IAEA Tecdoc Series: Geological Classification of Uranium Deposits and Description of Selected Examples; International Atomic Energy Agency: 
Vienna, 2018;

5. BAKOSURTANAL Peta Rupabumi Lembar Nanga Pinoh, Kalimantan; 2004;

6. Sutjipto, R.H. Sedimentology of the Melawi and Kentungau Basins, West Kalimantan, Indonesia, University of Wollongong, 1991.

7. Amiruddin; Trail, D.S. Peta Geologi Lembar Nanga Pinoh Kalimantan Skala $1: 250.000$; Bandung, 1993;

8. Rose, A.W.; Wright, R.J. Geochemical exploration models for sedimentary uranium deposits. J. Geochemical Explor. 1980, 13, 153-179, doi:10.1016/0375-6742(80)90005-9.

9. Xueqiu, W.; Bimin, Z.; Xin, L.; Shanfa, X.; Wensheng, Y.; Rong, Y. Geochemical challenges of diverse regolith-covered terrains for mineral exploration in China. Ore Geol. Rev. 2016, 73, 417-431, doi:10.1016/j.oregeorev.2015.08.015.

10. Wu, L.; Jiao, Y.; Roger, M.; Yang, S. Sedimentological setting of sandstonetype uranium deposits in coal measures on the southwest margin of the TurpanHami Basin , China. J. Asian Earth Sci. 2009, 36, 223-237, doi:10.1016/j.jseaes.2009.06.003.

11. Hu, F.; Li, J.; Liu, Z.; Zhao, D.; Wan, T.; $\mathrm{Xu}, \mathrm{C}$. Sequence and sedimentary characteristics of upper Cretaceous Sifangtai Formation in northern Songliao Basin, northeast China: Implications for sandstone-type uranium mineralization. Ore Geol. Rev. 2019, 111, 102927, doi:10.1016/j.oregeorev.2019.05.013.

12. Haryanto, I. Kontrol Struktur Geologi Terhadap Sebaran Batubara di Daerah Menukung-Nangapinoh Kalimantan Barat. Bull. Sci. Contrib. 2008, 6, 103110.

13. Hou, B.; Keeling, J.; Li, Z. Paleovalleyrelated uranium deposits in Australia and China: A review of geological and exploration models and methods. Ore Geol. Rev. 2017, 88, 201-234, doi:10.1016/j.oregeorev.2017.05.005.

14. Carranza, J. General Procedures of Geochemical Exploration; Bangkok, 2017;

15. Wenrich-Verbeek, K.J. Uranium and Coexisting Element Behavior in Surface Waters and Associated Sediments with Varied Sampling Techniques Used for Uranium Exploration. J. Geochemical Explor. 1977, 8, 337-355.

16. Price, V.; Ferguson, R.B. Stream Sediment Geochemical Surveys for Uranium. J. Geochemical Explor. 1980, 13, 285-304. 